\title{
Pendidikan Nilai Karakter Dan Spiritual Berbasis Komunitas di MI Miftahul Huda Dono-Sendang Kabupaten Tulungagung
}

\author{
Meyta Dewi Anggarwati ${ }^{1 *}$ \\ 1UIN Sunan Kalijaga Yogyakarta, meytadewi9@gmail.com
}

\begin{abstract}
The essence of education is basically not only a matter of transfer of knowledge, but also the transfer of values, in the sense that sticking values and practices will be very significant in the formation of noble and good character of students, not just memorizing and knowing. Character education is a very urgent matter to be discussed and further developed both in the theoretical and practical framework, therefore teachers and educators have a clearer picture and deeper knowledge of the experience of institutions that continuously expand in the implementation of education. to achieve good character of students. The problems presented in this study are: how is the implementation of character education in the Miftahul Huda Ibtidaiyah Madrasah. The purpose of this study was: to understand the process of implementing character education at Miftahul Huda Islamic School. This research is a field research with a qualitative approach. The subject of this study was MI Miftahul Huda. The process of collecting data is done by observation and interviews. The results showed that, first, the implementation of character value education in Ibtidaiyah Miftahul Huda Madrasah was basically the development of al-Karimah moral education which was implemented in several aspects.

Keyword: (a) curriculum, (b) madrasa culture, and (c) development program self.
\end{abstract}

\begin{abstract}
ABSTRAK
Inti dari pendidikan pada dasarnya bukan hanya masalah transfer pengetahuan, tetapi juga transfer nilai-nilai, dalam arti bahwa nilai-nilai pelekatan dan praktik-praktik tersebut akan sangat signifikan dalam pembentukan karakter mulia dan baik siswa, tidak hanya hanya menghafal dan mengetahui. Pendidikan karakter menjadi hal yang sangat mendesak untuk dibahas dan dikembangkan lebih lanjut baik dalam kerangka teoritis maupun yang praktis, oleh karena itu guru dan pendidik memiliki gambaran yang lebih jelas dan pengetahuan yang lebih dalam dari pengalaman institusi yang terus menerus melakukan ekspansi dalam pelaksanaan pendidikan. untuk mencapai karakter baik siswa. Permasalahan yang disajikan dalam penelitian ini adalah: bagaimanakah pelaksanaan pendidikan karakter di Madrasah Ibtidaiyah Miftahul Huda. Tujuan penelitian ini adalah: untuk memahami proses pelaksanaan pendidikan karakter di Madrasah Ibtidaiyah Miftahul Huda. Penelitian ini merupakan penelitian lapangan dengan pendekatan kualitatif.
\end{abstract}


Subyek penelitian ini adalah MI Miftahul Huda. Proses pengumpulan data dilakukan dengan cara observasi dan wawancara. Hasil penelitian menunjukkan bahwa, pertama, pelaksanaan pendidikan nilai karakter di Madrasah Ibtidaiyah Miftahul Huda pada dasarnya merupakan pengembangan pendidikan akhlak al - Karimah yang diimplementasikan dalam beberapa aspek, yaitu: (a) kurikulum, (b) budaya madrasah, dan (c) program pengembangan diri.

Kata kunci: pendidikan nilai, nilai karakter, pendidikan spiritual.

Article history

Received: 21-01-2020

Revised: 07-02-2020

Accepted: 05-06-2020

Copyright (c) 2020 Anggarwati

\section{PENDAHULUAN}

Pendidikan di Indonesia selama ini masih mengedepankan aspek kognitif atau akademis, sedangkan aspek soft skills atau non akademis yang mendukung pendidikan karakter belum banyak mendapat perhatian (Judiani, 2011).

Sehingga pelaksanaan pendidikan karakter ini menjadi hal yang sangat signifikan untuk diimplementasikan. Pendidikan karakter juga berorientasi pada tujuan pendidikan yang mengarahkan pada kecerdasan mental, disamping pada pencapaian tujuan akademis semata. Khusus pada level pendidikan dasar, pendidikan karakter ini diintegrasikan dalam mata pelajaran yang sudah ada, seperti muatan lokal, pengembangan diri, dan budaya sekolah.

Pendidikan yang menghasilkan warga negara yang baik digambarkan sebagai pendidikan yang menekankan pada nation and character building dengan cara menanamkan nilai karakter dan spiritual agar terbentuk manusia Indonesia seutuhnya. Pendidikan tidak cukup jika hanya membelajarkan anak menjadi pandai dan mengusai teknologi. Pendidikan harus sadar dan bertujuan untuk membantu anak menjadi manusia berbudi pekerti dan menanamkan kebiasaan baik sehingga peserta didik dapat memahami (kognitif), merasakan da membuat pilihan (afektif), dan 
menerapkannya dalam tingkah laku hidup keseharian (psiko-motorik) tanpa dipaksa.

Ini merupakan tantangan bagi para pendidik terlebih pada mereka yang berada di madrasah. Bisa dikatakan ironis ketika para guru madrasah mengajarkan para siswanya tentang ayat dan hadits yang berkaitan dengan beribu kebaikan dan amal shaleh semisal menjaga kebersihan akan tetapi tidak disertai dengan langkah nyata dalam mengamalkan kebaikan dan amal shaleh tersebut.

Madrasah Ibtidaiyah Miftahul huda Dono-Sendang ini merupakan lembaga setingkat Sekolah Dasar di bawah naungan Kementrian Agama yang tumbuh dan berkembang sesuai dengan kebutuhan dan tuntunan masyarakat. Lembaga ini berkembang karena adanya faktor kesungguhan dan kedisiplinan, dukungan wali murid, terpeliharanya lingkungan dan layanan, sertaterus berupaya untuk meraih prestasi akademik maupun non akademik. "Terbentuknya Generasi yang Unggul, Tangguh
Serta Berprestasi Berdasarkan Iman dan Taqwa" adalah visi yang telah benar-benar mengantarkan MI Miftahul Huda ini dalam meraih prestasi baik di bidang akademik maupun non akademik.

\section{A. Landasan Teori}

1. Pendidikan Nilai

Mulyana (2004) mengartikan pendidikan nilai sebagai penanaman dan pengembangan nilai-nilai serta menempatkannya secara integral dalam keseluruhan hidupnya. Pendidikan nilai tidak hanya merupakan program khusus yang diajarkan melalui sejumlah mata pelajaran, akan tetapi mencakup keseluruhan program pendidikan.

Pendidikan nilai merupakan proses bimbingan melalui suri tauladan pendidikan yang berorintasi pada penanaman nilainilai kehidupan yang didalamnya mencakup nilai agama, budaya, etika, dan estetika menuju pembentukan pribadi peserta didik yan memiliki kecerdasan spiritual keagamaan, pengendalian diri, kepribadian yang utuh, berakhlak 
mulia, serta ketrampilan yang diperlukan dirinya, masyrakat dan negara (Sumantri 2007;134)

Pendidikan Nilai mengandung tiga unsur utama yaitu ontologis Pendidikan Nilai, epistemologis Pendidikan Nilai dan aksiologis Pendidikan Nilai.

1) Dasar Ontologis Pendidikan Nilai Pertama-tama pada latar filsafat diperlukan dasar ontologis dari Pendidikan Nilai. Adapun aspek realitas yang dijangkau teori dan Pendidikan Nilai melalui pengalaman panca indera merupakan dunia pengalaman manusia secara empiris. Objek materil Pendidikan Nilai adalah manusia seutuhnya, manusia yang lengkap aspek-aspek kepribadiannya. Objek formal Pendidikan Nilai dibatasi pada manusia seutuhnya di dalam fenomena atau situasi pendidikan. Di dalam situasi sosial, manusia sering kali berperilaku tidak utuh, hanya menjadi mahluk berperilaku individual dan/atau mahluk sosial yang berperilaku kolektif.
Sistem nilai harus terwujud dalam hubungan inter dan antar pribadi yang menjadi syarat mutlak (conditio sine qua non) bagi terlaksananya mendidik dan mengajar. Hal itu terjadi mengingat pihak pendidik yang berkepribadian sendiri secara utuh memperlakukan peserta didik secara terhormat sebagai pribadi pula. Jika pendidik tidak bersikaf afektif utuh demikian maka akan menjadi mata rantai yang hilang (the missing link) atas faktor hubungan peserta didik-pendidik atau antara siswa-guru. Dengan begitu pendidikan hanya akan terjadi secara kuantitatif sekalipun bersifat optimal, sedangkan kualitas manusianya belum tentu utuh.

2) Dasar Epistemologis Pendidikan Nilai

Dasar epistemologis diperlukan oleh pendidikan nilai atau pakar pendidikan nilai demi mengembangkan ilmunya secara produktif dan bertanggung jawab. Pendidikan Nilai memerlukan pendekatan fenomenologis yang akan menjalin studi empirik dengan studi kualitatif fenomenologis. 
Karena penelitian tidak hanya tertuju pada pemahaman dan pengertian, melainkan untuk mencapai kearifan fenomena pendidikan.

3) Dasar Aksilogis Pendidikan Nilai. Kemanfaatan teori Pendidikan Nilai tidak hanya perlu sebagai ilmu yang otonom tetapi juga diperlukan untuk memberikan dasar yang sebaik-baiknya bagi pendidikan sebagai proses pembudayaan manusia secara beradab. Oleh karena itu nilai pendidikan nilai tidak hanya bersifat intrinsik sebagai ilmu seperti seni untuk seni, melainkan juga nilai ekstrinsik. Dan ilmu digunakan untuk menelaah dasar-dasar kemungkinan bertindak dalam praktek melalui kontrol terhadap pengaruh yang negatif dan meningkatkan pengaruh yang positif dalam pendidikan. Dengan demikian pendidikan nilai tidak bebas nilai, mengingat hanya terdapat batas yang sangat tipis antar pekerjaan pendidikan nilai dan tugas pendidik sebagai pedagok. Dalam hal ini, sangat relevan sekali untuk memperhatikan pendidikan nilai sebagai bidang yang sarat nilai. 174
Itulah sebabnya pendidikan nilai memerlukan teknologi pula, tetapi pendidikan bukanlah bagian dari iptek. Namun harus diakui bahwa pendidikan nilai belum jauh pertumbuhannya dibandingkan dengan kebanyakan ilmu sosial dan ilmu perilaku.

2. Nilai Karakter

Adapun kata karakter merupakan istilah serapan dari bahasa Inggris character. Encarta Dictionaries menyatakan bahwa karakter adalah kata benda yang memiliki arti: (1) kualitas-kualitas pembeda; (2) kualitas-kualitas posistif; (3) reputasi; (4) seseorang dalam buku atau film; (5) orang yang luar biasa; (6) individu dalam kaitannya dengan kepribadian, tingkah laku atau tampilan; (7) huruf atau simbol; (8) unit data komputer. Arti pada nomor (7) dan (8) ini tidak relevan dengan kajian pendidikan karakter (Kesuma, Triatna, dan Permana. 2011: 23). Untuk lebih memperjelas pengertian karakter, dalam kamus umum bahasa Indonesia, karakter diartikan sebagai tabiat; watak; sifat-sifat kejiwaan; akhlak; atau budi pekerti 
yang membedakan seseorang dengan yang lainnya

(Poerwadarminta, 2006: 521).

Dari sumber di atas, penulis menyimpulkan bahwa karakter adalah watak, tabiat, atau akhlak seseorang yang akan mampu menjadi kualitas pembeda orang tersebut dari yang lainnya. Meskipun karakter ini masih bersifat umum, namun dalam pemaknaannya kata karakter lebih diartikan dengan sebuah tabiat, watak, dan akhlak yang baik atau mulia. Di samping itu Thomas Lickona (1991) menekankan 3 bagian karakter yang saling berkaitan, yaitu pengetahuan tentang moral (moral knowing), perasaan (moral felling), dan perilaku bermoral (moral behavior). Karakter yang baik terdiri dari mengetahui kebaikan (knowing the good), mencintai atau menginginkan kebaikan (loving or desiring thegood) dan melakukan kebaikan (acting the good). Dari beberapa penjelasan di atas maka yang dimaksud dengan nilai karakter dalam penelitian ini adalah nilai-nilai yang ditanamkan

Menurut Koesoema (2011: 205) bahwa nilai-nilai yang ditanamkan dalam pendidikan karakter melibatkan berbagai macam komposisi nilai, antara lain nilai agama, nilai moral, nilainilai umum, dan nilai-nilai kewarganegaraan. Menurut Kementerian Pendidikan Nasional (2010) sumber nilai karakter itu menjadi empat, yakni agama, pancasila, budaya, dan tujuan pendidikan nasional. Dari empat sumber tersebut teridentifikasi beberapa nilai karakter, yakni: religius, jujur, toleransi, disiplin, 
kerja keras, kreatif, mandiri, demokratis, rasa ingin tahu, semangat kebangsaan, cinta tanah air, menghargai prestasi, bersahabat/komuniktif, cinta damai, gemar membaca, peduli lingkungan, peduli sosial, dan tanggungjawab (Kementerian Pendidikan Nasional, 2010; 8-9). Adapun beberapa pendekatan yang bisa digunakan dalam pendidikan nilai (karakter), antara lain:

a. Pendekatan penanaman nilai (inculcation approach) adalah suatu pendekatan yang memberi penekanan pada penanaman nilai-nilai (karakter) dalam diri siswa. Tujuan pendidikan nilai menurut pendekatan ini adalah diterimanya nilai-nilai sosial (karakter baik) oleh siswa dan berubahnya nilai-nilai siswa yang tidak sesuai dengan nilainilai sosial (karakter buruk). Metode yang digunakan dalam proses pembelajaran menurut pendekatan ini antara lain: keteladanan, penguatan positif dan negatif, simulasi, bermain peran, dan lain-lain. b. Pendekatan perkembangan kognitif. Pendekatan ini dikatakan pendekatan perkembangan kognitif karena karakteristiknya memberikan penenakanan pada aspek kognitif dan perkembangannya. Pendekatan ini mendorong siswa untuk berpikir aktif tentang masalah-masalah moral dan dalam membuat keputusankeputusan moral. Metode yang digunakan dalam proses pembelajaran menurut pendekatan ini adalah metode diskusi kelompok. Proses diskusi dimulai dengan penyajian cerita yang mengandung dilema, dalam diskusi tersebut siswa didorong untuk menentukan posisi apa yang sepatutnya dilakukan oleh orang yang terlibat, apa alasanalasannya.

c. Pendekatan analisis nilai (values analysis approach) memberikan penekanan pada perkembangan kemampuan siswa untuk berpikir logis, dengan cara menganalisis masalah yang berhubungan dengan nilai-nilai sosial. Metode pembelajaran 
yang sering digunakan menurut pendekatan ini adalah pembelajaran secara individu atau kelompok tentang masalahmasalah sosial yang memuat nilai-nilai moral, penyelidikan kepustakaan, penyelidikan lapangan, dan diskusi kelas berdasarkan kepada pemikiran rasional.

d. Pendekatan klarifikasi nilai (values clarification approach) memberi penekanan pada usaha membantu siswa dalam mengkaji perasaan dan perbuatannya sendiri untuk meningkatkan kesadaran mereka tentang nilainilai (karakter) mereka sendiri. Metode yang digunakan dalam proses pembelajaran menurut pendekatan ini adalah metode dialog, menulis, diskusi dalam kelompok besar atau kecil, dan lainlain.

e. Pendekatan pembelajaran berbuat (action learning approach) memberi penekanan pada usaha memberikan kesempatan kepada siswa untuk melakukan

perbuatan- perbuatan moral, baik secara perseorangan maupun secara bersama-sama dalam suatu kelompok. Metode-metode lain yang digunakan juga adalah proyek-proyek tertentu untuk dilakukan di sekolah atau dalam masyarakat seperti halnya program-program pembiasaan yang dilakukan di madrasah atau sekolah, dan praktek keterampilan dalam berorganisasi serta berhubungan antara sesama. (El-Mubarok, 2006: 61-73)

3. Pendidikan spriritual

Spiritual berasal dari kata spirit yang berarti jiwa atau sukma atau roh. Spiritual berarti kejiwaan, rohani, batin, mental atau moral.s Pendidikan spiritual dalam kajian agama pada dasarnya merupakan usaha konservasi atas ajaran-ajaran agama dalam rangka memupuk keimanan dan kepercayaan, yang dilakukan personal (perorangan) atau komunitas agama yang bersangkutan.pendidikan spiritual merupakan usaha bagi para pemeluk untuk memberikan respon terhadap 
ajaran agamanya atau pemikiran dari luar agama yang diyakini. Pendidikan spiritual sebagai transmisi ajaran agama dari generasi ke generasi dan karenanya hal ini tidak hanya melibatkan aspek kognitif (pengetahuan tentang ajaran agama) saja, namun aspek avektif dan psikomotorik (sikap dan pengalaman ajaran islam) juga merupakan hal pokok.

Pendidikan spiritual dikenal sebagai proses pendidikan kepribadian yang didasarkan kepada kecerdasan emosional dan spiritual (ruhaniah) yang bertumpu pada masalah self atau diri. Keseimbangan menggunakan kecerdasan emosional dan spiritual dalam pembentukan kepribadian akan menciptakan insan kamil, sekaligus mampu menjadi umat yang memiliki kesalehan individu dan kesalehan sosial.

Hasan Al-Bana mengatakan bahwa pendidikan spiritual adalah tarbiyah ruhiyah yang bertujuan untuk memperkuat barisan cara a'aruf. Maksudnya ialah memperkuat jiwa dan ruh, menginspirasi adat dan tradisi, terus menerus dalam menjaga hubungan baik dengan Allah, dan senantiasa memohon pertolongan dari-Nya. Tanpa mengesampingkan aktivitasnya dalam kehidupannya di dunia, dengan kata lain senantiasa menjaga keseimbangan kebutuhan dunia dan akhirat.

Pendidikan spritual adalah pendidikan berdasarkan pengalaman yang dilakukan secara sadar untuk mengarahkan ruhani agar tetap berjalan sesuai dengan fitrahnya yaitu beriman kepada-Nya dan mengembangkan potensi Ilahiyah sampai puncak dari keimanan kepada Allah, sehingga ruhaniahnya pun dapat mendorong aktivitas fisiknya atu tindakan sehari-hari agar selalu berjalan sesuai dengan syariat Allah.

Menurut Al-Ghazali manusia di ciptakan sebagai makhluk yang terdiri dari jiwa dan jasad. Jiwa, yang menjadi inti hakikat manusia adalah makhluk spiritual rabbani yang sangat halus. Jiwa berada di alam spiritual sedangkan jasad di alam materi. Jiwa berasal dari ilahi yang mempunyai potensi kodrati yaitu kecenderungan kepada kebaikan dan keengganan kepada kekejian. Fitrah 
jiwa ini cenderung mendapatkan nur yang mana AL-Ghazali menyebutnya sebagai ma'rifat kedalam hatinya, ia dapat menerima kebenaran pengetahuan yang datangnya dari Allah SWT. Sehingga dengan ma'rifat kedalam hati para salik (pelaku spiritual) lebih mendekatkan diri kepada Allah. Pada hakikatnya jiwa manusia itu mempunyai potensi kodrati yang cenderung mengarah kepada kebaikan karena mendapatkan nur sehingga dapat mendekatkan diri kepada Allah.

\section{METODE PENELITIAN.}

Untuk mengungkap seputar pelaksanaan pendidikan nilai karakter di Madrasah Ibtidaiyah Miftahul huda Dono-Sendang peneliti menggunakan metode penelitian kualitatif. Penelitian kualitatif pada hakikatnya adalah mengamati orang dalam lingkungan hidupnya, berinteraksi dengan mereka, dan berusaha memahami pemikiran mereka tentang dunia sekitarnya.

Dalam penelitian ini yang diamati adalah peserta didik di Madrasah Ibtidaiyah Miftahul huda DonoSendang. Pengumpulan data dilakukan dengan menggunakan dua metode yakni wawancara dan observasi. Di mana yang menjadi narasumber dalam penelitian ini adalah kepala Madrasah.

\section{HASIL DAN PEMBAHASAN}

Observasi ini dilakukan di Madrasah Ibtidaiyah Dono Sendang Kabupaten Tulungagung, yang mana subjek dari penelitian ini adalah para peserta didik di Madrasah tersebut. Madrasah ini merupakan salah satu sekolah yang berbasis Islam yang ada di Kabupaten Tulungagung Kecamatan Sendang. Dalam penelitian ini yang menjadi sumber utama adalah bapak Asrori sebagai kepala Madrasah dan beberapa wali murid yang ada di lingkungan Madrasah.

Adapun hasil observasi yang penulis lakukan di Madrasah Ibtidaiyah Miftahul huda DonoSendang ini sudah memiliki konsep menanamkan pendidikan nilai dan spiritual. Tidak lain konsep penanaman nilai dan spiritual yang dilakukan ini guna membentuk akhlak al-karimah yang dipadukan dengan konsep pendidikan budaya 
karakter bangsa (Wawancara Kepala Sekolah, 12/05/2018).

\section{Konsep penanaman}

pendidikan nilai karakter dan spiritual di Madrasah Ibtidaiyah Miftahul huda Dono-Sendang ini di laksanakan secara berkelanjutan dari mulai kelas I hingga kelas VI dengan memperhatikan psikologis serta jenjang kelas peserta didik. Konsep ini pun bukan merupakan suatu mata pelajaran yang mana di ajarkan kepada peserta didik melainkan suatu nilai yang masuk ke dalam semua mata pelajaran.

Konsep dasar pendidikan nilai karakter dan spiritual di Madrasah Ibtidaiyah Miftahul huda DonoSendang ini dilandaskan pada visi, misi dan tujuan madrasah, dan diimplementasikan ke dalam beberapa bagian diantaranya:

1) kurikulum dan mata pelajaran,

2) budaya madrasah baik di lingkungan guru maupun siswa, 3) pengembangan diri melalui program pembiasaan dan pengembangan minat dan bakat siswa.

1) Kurikulum dan Mata Pelajaran.
Adapun kurikulum yang dilakukan Madrasah Ibtidaiyah Miftahul huda Dono-Sendang yang berkaitan dengan penanaman nilai karakter dan spiritual adalah sebagai berikut:

- Memperbanyak jam mata pelajaran, di Madrasah Ibtidaiyah Miftahul huda DonoSendang memiliki jam tambahan untuk mata pelajaran rumpun PAI yang berisi tentang nilai-nilai karakter spiritual. Ada pun beberapa mata pelajaran rumpun PAI yang diberikan adalah Aqidah Akhlak, Fiqih, AlQur'an Hadist dan SKI (Sejarah Kebudayaan Islam), yang mana pelajaran ini tidak di berikan di sekolah-sekolah dasar lain.

- Adanya program pembiasaan. Program pembiasaan yang dilakukan di sekolah ini adalah melakukan apel pagi, apel pagi ini merupakan kegiatan berdo'a bersama sebelum belajar selain itu di apel pagi para peserta didik juga di ajak untuk melafadzkan Asmaul Husna dan surat-surat pendek. Ini dilakukan dengan tujuan agar semua siswa yang sudah hafal tetap menjaga 
hafalannya dengan baik dan benar, sementara untuk siswa yang belum hafal mampu dan bisa belajar dengan cara mendengar dan mengikuti bacaan temannya yang sudah hafal. Selain pembiasaan apel pagi, Madrasah Ibtidaiyah Miftahul huda Dono-Sendang ini juga memiliki pembiasaan lain yaitu siswa kelas III sampai kelas VI diwajibkan melaksanakan sholat dhuha di jam istirahat dan sholat zuhur berjama'ah sebelum pulang sekolah dengan pengawasan guru/wali kelas masing-masing.

2) Budaya Madrasah

Salah satu budaya guru Madrasah Ibtidaiyah Miftahul huda Dono-Sendang yang sempat dikatakan oleh Bpk Asrori sebagai kepala Madrasah Ibtidaiyah Miftahul huda DonoSendang, adalah: a) adanya budaya disiplin dan tepat waktu untuk masuk sekolah sebelum pukul 06.45 WIB. b) adanya budaya religi guru untuk mengikuti pembiasaan yang telah dijelaskan di atas pada waktu yang telah ditentukan. c) adanya budaya guru untuk memeriksa kebersihan dan kerapian siswa pada saat setelah apel pagi sebelum barisan dibubarkan untuk masuk ke kelas masing-masing. Beberapa budaya tersebut diharapakan menjadi mampu menjadi suatu contoh suri taulada bagi para siswa di Madrasah Ibtidaiyah Miftahul huda Dono-Sendang ini.

3) Pengembangan Diri

Implementasi dari konsep penanaman nilai karakter dan spiritual di Madrasah Ibtidaiyah Miftahul huda Dono-Sendang selanjutnya adalah melalui program pengembangan diri. Adapun program pengembangan diri ini adlah berbagai macam program tambahan di luar proses pembelajaran reguler yang di selenggarakan oleh pihak madrasah guna menunjang terwujudnya karakter atau kepribadian peserta didik. Pengembangan diri ini terdiri dari beberapa pengembangan 
minat dan bakat atau ekstrakurikuler yang di antaranya yakni: pramuka, drum band, qiraah dll.

\section{KESIMPULAN}

Pentingnya

pendidikan

karakter di sekolah sebagai tempat mendidik generasi penerus bangsa. Hal ini berangkat dari kondisi obyektif dalam kehidupan masyarakat Indonesia saat ini telah terjadi penyimpangan-penyimpangan seperti kekerasan korupsi, manipulasi, kebohongankebohongan, tidak adanya panutan dan keteladanan dikalangan para pemimpin, kepalsuan, pelanggaran dan pemutar balikan hukum. Hal ini mendorong dunia pendidikan untuk memberikan pendidikan karakter walaupun sudah terlambat, tetapi lebih baik dari pada tidak memulai.

Adapun pendidikan karakter di sekolah dilakukan dengan berbagai metode yang dapat dilakukan oleh guru atau lembaga pendidikan yaitu: Metode pembinaan yang diformulasikan melalui 4M, yaitu mengetahui kebaikan (knowing the good), mencintai kebaikan (loving the good), menginginkan kebaikan (de siring the good), dan mengerjakan kebaikan (acting the good).

\section{DAFTAR PUSTAKA}

El-Mubarok, Zaim. 2006. Membumikan Pendidikan Nilai. Bandung: Alfabeta.

Judiani, S. 2010. Implementasi Pendidikan Karakter Di Sekolah Dasar Melalui Penguatan Pelaksanaan Kurikulum. Jurnal Pendidikan dan Kebudayaan. $16(3)$

Kesuma, Dharma. Triatna, Cepi Permana, Johar. 2011. Pendidikan Karakter; Kajian Teori dan Praktik di Sekolah. Bandung: Remaja Rosdakarya.

Kementerian Pendidikan Nasional. 2010. Pengembangan Pendidikan Budaya dan Karakter Bangsa; Pedoman 
Sekolah. Jakarta: Balitbang

Pusat Kurikulum.

Koesoema, Doni A. 2011. Pendidikan

Karakter Strategi Mendidik

Anak di Zaman Global. Jakarta: PT Gramedia.

Lickona, Thomas. (1991). Education for character: how our school can teach respect and responsibility. New York, Toronto,London, Sydney, Aucland:Bantam Books.

Mulyana, Rohmat. 2004. Mengartikulasikan

Pendidikan Nilai. Bandung: Alfabeta

Poerwadarminta, W. J. S. 2006. Kamus Umum Bahasa Indonesia Edisi Ketiga. Jakarta: Balai Pustaka.

Sumantri, E. (2007). Pendidikan Nilai Kontemporer. Bandung: Program studi PU UPI. 